\title{
Combined effects of chemical dip and/or carrageenan coating and/or controlled atmosphere on quality of fresh-cut banana
}

\author{
S.L.S. Bico, M.F.J. Raposo, R.M.S.C. Morais, A.M.M.B. Morais * \\ Escola Superior de Biotecnologia da Universidade Católica Portuguesa, Rua Dr. António Bernardino de Almeida, 4200-072 Porto, Portugal
}

Keywords:

Fresh-cut banana

Ascorbic acid

Calcium chloride

Cysteine

Carrageenan

Controlled atmosphere

\begin{abstract}
A B S T R A C T
The combined effect of chemical dip and/or edible coating and/or controlled atmosphere (CA) on quality of fresh-cut banana was investigated. Banana slices were subject to a 3-min dip into a solution containing $1 \%(\mathrm{w} / \mathrm{v})$ calcium chloride, $0.75 \%(\mathrm{w} / \mathrm{v})$ ascorbic acid and $0.75 \%(\mathrm{w} / \mathrm{v})$ cysteine and/or combined with a carrageenan coating and/or combined with controlled atmosphere $\left(3 \% \mathrm{O}_{2}+10 \% \mathrm{CO}_{2}\right)$. Physico-chemical and microbiological qualities were evaluated during 5 days of storage at $5{ }^{\circ} \mathrm{C}$. Dip combined with $\mathrm{CA}$ treatment prevented product weight loss and increase of polyphenol oxidase activity during the 5 days of storage. Colour, firmness, $\mathrm{pH}$, tritatable acidity and total soluble solids values and total phenolic content presented the smallest changes. Microbial analysis showed that minimally processed bananas were within the acceptable limits during 5 days of storage at $5{ }^{\circ} \mathrm{C}$.
\end{abstract}

\section{Introduction}

Production of fresh-cut fruits is becoming an important task in food industry because of their convenience as ready-to-eat products as well as for the health benefits associated with their consumption. Fresh-cut fruits, as living tissues, undergo enzymatic browning and softening, microbial contamination, and undesirable volatile production which result in shorter shelf life than the whole produce (Soliva-Fortuny \& Martin-Belloso, 2003).

Fresh-cut banana slices have a faster rate of browning and softening because of wounding (Vilas-Boas \& Kader, 2006).

Over the years, different physical and chemical techniques have been developed to extend the shelf life of fresh-cut produce: refrigeration, disinfection (Hong \& Gross, 1998), ethylene absorbers (Abe \& Watada, 1991), gamma irradiation (Chervin \& Boisseau, 1994), edible coating (Baldwin, Nisperos-Carriedo, \& Baker, 1995), chemical dipping (Vilas-Boas \& Kader, 2006) and controlled/modified atmosphere (Brecht, 1999). Because different fruits react differently to different treatments, it is imperative that the right combination of these treatments is determined in order to extend its shelf life.

Application of calcium compounds helps to maintain firmness of fresh-cut banana (Vilas-Boas \& Kader, 2006). A 2-min dip in a mixture of $1 \%(\mathrm{w} / \mathrm{v})$ calcium chloride $+1 \%(\mathrm{w} / \mathrm{v})$ ascorbic acid $+0.5 \%(\mathrm{w} / \mathrm{v})$ cysteine effectively prevented browning and soft-

\footnotetext{
* Corresponding author. Fax: +351 225090351.

E-mail address: abmorais@esb.ucp.pt (A.M.M.B. Morais).
}

ening of banana slices for 6 days at $5{ }^{\circ} \mathrm{C}$. Dips in less than $0.5 \%$ cysteine promoted pinking of fresh-cut banana slices, while concentrations between $0.5 \%$ and $1.0 \%$ delayed browning and extended the post-cutting life to 7 days at $5{ }^{\circ} \mathrm{C}$ (Vilas-Boas \& Kader, 2006). Furthermore, fresh-cut banana treated with chemical dip at $\mathrm{pH} 2.5$ showed a longer shelf life in terms of firmness than $\mathrm{pH}$ 7.0.

MA helps to maintain freshness of fresh-cut produce by inhibiting metabolic activity, ethylene sensitivity and production, and/or physiological and pathological deterioration during storage (Gorris \& Tauscher, 1999). However, level of oxygen and/or carbon dioxide should be regulated as respiration of the product becomes anaerobic when oxygen levels decline too much (McHugh \& Senesi, 2002), leading to accumulation of ethyl alcohol, or anaerobic metabolism (normally below $1 \% \mathrm{O}_{2}$ ) that leads to off - flavours (Purvis, 1983). Combination of $2-5 \% \mathrm{O}_{2}$ and $2-5 \% \mathrm{CO}_{2}$ was found to delay ripening and reduce respiration and ethylene production rates of whole banana fruit (Kader, 2005).

The basic composition of edible coating for fresh-cut fruits may include hydrocolloids and lipids. These hydrocolloids (proteins and carbohydrates) tend to form hydrophilic networks, usually being a good barrier to oxygen and carbon dioxide, but a poor barrier to water. Some polysaccharides that have been successfully used to coat fresh-cut fruits include carrageenan, maltodextrin, methylcellulose, carboxymethyl cellulose, pectin, alginate, chitosan, starch, and microcrystalline cellulose (Debeaufort, Quezada-Gallo, \& Voilley 1998; Olivas, Rodriguez, \& Barbosa-Cánovas, 2003; Pavlath, Wong, \& Kumosinski, 1993; Rouse \& Moore, 1972; Thommohaway, 
Uthairatanakij, Kanlayanarat, \& Jitareerat, 2007; Wong, Tillin, Hudson, \& Pavlath, 1994).

Functional, nutritional, organoleptic and mechanical properties of coatings can be improved by the use of additives like antibrowning agents, preservatives, firming agents, plasticizers, nutraceuticals, volatile precursors, flavours and colours (Baldwin, Nisperos, Chen, \& Hagenmaier, 1996; Vojdani \& Torres 1990). Glycerol and polyethylene glycol are the most often used plasticizers for cut fruits (Wong et al., 1994). These substances have the ability to modify the mechanical properties of the coatings by moving polymer chains apart and reducing the rigidity of the structures (Guilbert \& Biquet, 1996).

Some studies have been conducted on the effect of combination of chemical dip and/or CA and/or coating. Vilas-Boas and Kader (2006) studied the effect of combination of chemical dip and atmosphere composition on fresh-cut banana. They found that combination of CA $\left(2 \mathrm{kPa} \mathrm{O}+10 \mathrm{kPa} \mathrm{CO}_{2}\right)$ with chemical dip (1\% $\mathrm{CaCl}_{2}, 1.0 \%$ ascorbic acid and $0.5 \%$ cysteine) did not prevent changes in firmness of fresh-cut bananas further than the chemical dip alone, while Aguayo, Escalona, and Artés (2008) also found that combination of calcium dip ( $\left.1 \% \mathrm{w} / \mathrm{v} \mathrm{CaCl}_{2}\right)+\mathrm{CA}\left(3 \mathrm{kPa} \mathrm{O} \mathrm{O}_{2}+10 \mathrm{kPa}\right.$ $\mathrm{CO}_{2}$ ) had no additional effect on firmness retention of fresh-cut strawberries compared to these two treatments when provided separately.

Combination of edible coating, chemical dip and/or CA may then be useful in extending the shelf life of fresh-cut fruit, banana, in particular. There is little information about the combined effect of edible coating and/or chemical dip and/or CA on fresh-cut fruits. Moreover, only few research works have been conducted on freshcut banana. Therefore, the objectives of this study were to maintain the fresh-like quality of fresh-cut banana from Madeira Island (cv. Cavendish), by using chemical dipping combined with edible coating and/or controlled atmosphere, and to study the effects on physico-chemical and microbiological qualities of that fresh-cut produce.

\section{Materials and methods}

\section{Plant material}

Madeira bananas (cv. Cavendish) at ripeness stage 4 (peel more yellow than green) and free of visible physical and fungal infection were purchased from the central market of Porto, Portugal (MAP). The bananas were transferred to the laboratory and were stored at $13 \pm 1{ }^{\circ} \mathrm{C}$ and $65 \%$ relative humidity ( $\mathrm{RH}$ ) until processing.

\section{Preparation of chemical dip}

The chemical dip used in the experiment was: $1 \%(\mathrm{w} / \mathrm{v})$ calcium chloride, $0.75 \%(\mathrm{w} / \mathrm{v})$ ascorbic acid and $0.75 \%(\mathrm{w} / \mathrm{v})$ cysteine.

Sterilized distilled water was used in the preparation of the chemical dip solution to prevent contamination with microorganisms.

\section{Preparation of edible coating}

Coating was prepared according to Lee, Park, Lee, and Choi (2003). Carrageenan solution was prepared by dissolving $0.5 \mathrm{~g}$ carrageenan (GENUGEL CJ, CPKelco, San Diego, CA, USA) in $100 \mathrm{ml}$ sterilized distilled water. A 50:50 (w/w) mixture of glycerol and PEG 4000 (Merck, Darmstadt, Germany) was used as plasticizer $\left(0.75 \mathrm{~g} / \mathrm{g}\right.$ carrageenan). The solution was equilibrated at $70^{\circ} \mathrm{C}$ and stirred vigorously with a magnetic stirrer bar for $40 \mathrm{~min}$, on a heating plate. The solution was cooled down to room temperature prior to $\mathrm{pH}$ adjustment (5.6), by using $2.6 \mathrm{M}$ citric acid.

\section{Sample preparation}

Bananas were washed with running water, dipped into chlorinated water ( $7500 \mathrm{ppm}$ active chlorine) for $5 \mathrm{~min}$ and dried at room temperature with forced air. The banana was then peeled and sliced ( $1 \mathrm{~cm}$ thickness) with a sharp sterilized knife in a laminar flow chamber. Ten slices were taken from each banana. Three replicates of 10 slices from different bananas per treatment and per day were analysed for the effect of chemical dipping and/or edible coating and/or controlled atmosphere. The samples were placed in an ice bath immediately after cutting.

Tree different treatments were used: (1) dip alone, (2) dip + CA; (3) dip + coating + CA. For the three treatments, banana slices were dipped into the chemical solution for $3 \mathrm{~min}$. The excess solution was allowed to drip off the banana slices surface for 5 min on tissue paper, and stored in 300-ml glass flasks. For treatment 3, chemically dipped bananas were coated and the excess solution was drip off the surface of the slices for $1 \mathrm{~min}$, before storage in $300-\mathrm{ml}$ glass flasks. The glass flasks were then flushed with $3 \%$ $\mathrm{O}_{2}$ and $10 \% \mathrm{CO}_{2}$ for $10 \mathrm{~min}$ prior to storage. Time had been previously optimized to guarantee the desired atmosphere composition inside the flasks. All samples were stored at $5{ }^{\circ} \mathrm{C}$ and $55 \% \mathrm{RH}$.

Slices dipped in distilled water were used as control. The temperature of the chemical dip and the distilled water used were maintained at $5{ }^{\circ} \mathrm{C}$ while the coating solution, previously stored at $20^{\circ} \mathrm{C}$, was kept at room temperature.

\section{Gas concentration determination}

The composition of the atmosphere in the glass flasks containing the banana slices was analyzed using a gas chromatograph GC $14 \mathrm{~A}$ (Shimadzu Corporation, Kyoto, Japan) equipped with a thermal conductivity detector. Helium was the carrier gas. Gas concentrations were monitored daily and flushing was repeated whenever necessary.

\section{Quality evaluation of fresh-cut banana}

\section{-All determinations were performed in triplicate}

Colour : Colour on opposite sides of each slice was measured with a Minolta CR-300 hand-held trismulus reflectance colorimeter (Minolta Corporation, Ramsey, NJ, USA) in the CIE $L^{*} a^{*} b^{*}$ mode CIELAB colour space (Commission Internationale de L'Eclairage (CIE), 1978). Chroma (C) was calculated by using the formula $\mathrm{C}=\left(a^{* 2}+b^{* 2}\right)^{1 / 2}$. Ten slices per replicate were used.

Firmness : Firmness of each slice was determined with a TA.XT Plus Texture Analyser (Stable Micro Systems Ltd, Godalming, Surey, UK) by measuring the force required for a $2-\mathrm{mm}$ cylindrical probe to penetrate $10 \mathrm{~mm}$ into the cut surface at a rate of $5 \mathrm{~mm} \mathrm{~s}^{-1}$. Each slice was punctured thrice in each opposite side. A load of $20 \mathrm{~N}$ was used. Ten slices per replicate were used for the analysis.

Moisture and weight loss : A banana slice from each replicate was placed into a previously tared petri dish and was dried at $70{ }^{\circ} \mathrm{C}$ for $48 \mathrm{~h}$. After drying, the Petri dish was put in a desiccator to cool to room temperature. Weight was registered before and after drying by using an analytical balance (Sartorius BP 210 S, Goettingen, Germany). Weight loss was calculated according to the formula:

Weight loss $(\%)=100-100 \times \mathrm{DM}(\%)_{\text {Day } 0} / \mathrm{DM}(\%)_{\text {Day } N}$

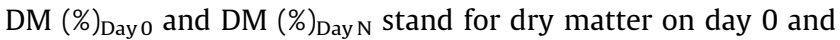
dry matter on day $N$, respectively.

$\mathrm{pH}$ and titratable acidity (TA) : Ten gram ( $10 \mathrm{~g})$ of banana from each replicate were crushed and homogenized with $100 \mathrm{ml}$ 
boiled distilled water (previously adjusted to $\mathrm{pH} 8.3$ ). The $\mathrm{pH}$ was measured by using pH meter Crison MicropH 2001 (Crison Instruments SA, Barcelona, Spain). The mixture was titrated with $0.10 \mathrm{M}$ $\mathrm{NaOH}$ to $\mathrm{pH} 8.3$ and the result was expressed as mg malic acid per $100 \mathrm{~g}$ sample.

Total soluble sugars (TSS) : TSS were determined according to Madamba (1993). Sugars from banana (0.2 g) were extracted with $10 \mathrm{ml} 80 \%(\mathrm{v} / \mathrm{v})$ ethanol, in a water bath $\left(80-85^{\circ} \mathrm{C}\right)$ for $30 \mathrm{~min}$. The supernatant was collected and the extraction was repeated twice. Ethanol in the supernatant was evaporated in the water bath, and the resulting solution was diluted to $50 \mathrm{ml}$.

A $0.50 \mathrm{ml}$ aliquot of this solution was allowed to react with $0.5 \mathrm{ml} 5 \%(\mathrm{w} / \mathrm{v})$ phenol solution and $2.5 \mathrm{ml}$ concentrated sulphuric acid. The absorbance was measured at $490 \mathrm{~nm}$ after 20 min by spectrophotometry (Shimadzu UV-Vis 1601, Kyoto, Japan) against a reagent blank. The total soluble sugars were calculated using a calibration curve (0.02-0.06 mg glucose $\mathrm{ml}^{-1}$ ) and the result was expressed in g glucose/100 $\mathrm{g}$ FW, and in g glucose/100 $\mathrm{g}$ DW.

Polyphenol oxidase (PPO) activity : PPO activity was determined according to Rocha and Morais (2001). In an external ice bath, one banana slice per replicate was homogenized with $25 \mathrm{ml}$ $0.2 \mathrm{M}$ phosphate buffer ( $\mathrm{pH} 6.5$ ) and $0.8 \mathrm{~g}$ polyvinylpolypirrolidone (PVPP) by using an Ultra-Turrax T25 homogenizer (Jank and Kunkel, IKA-Labortechnik, Breisgau, Germany) during 3 min with 1 min interval after each min. Two drops of Triton X-100 solution (Sigma Aldrich, Steinheim, Switzerland) was added before the last minute of homogenization. The mixture was centrifuged (Sorvall RC-5C, DuPont Company, Sorval Instruments, Wilmington, DE, USA) at $5010 \mathrm{rpm}$ and $4{ }^{\circ} \mathrm{C}$ for $15 \mathrm{~min}$. The volume of the centrifugate was recorded. An aliquot $(0.10 \mathrm{ml})$ of the centrifugate was added to the $2.80 \mathrm{ml}$ substrate solution $(1.1 \mathrm{~g}$ catechol in $50 \mathrm{ml}$ $0.05 \mathrm{M}$ phosphate buffer, $\mathrm{pH}$ 6.5) just before the assay, and the rate of increase in absorbance at $420 \mathrm{~nm}$ was monitored using a spectrophotometer (Shimadzu UV-Vis 1601, Japan). The substrate solution $(2.90 \mathrm{ml})$ was used as a reference blank. The linear section on of the activity curve as a function of time was used to determine the enzyme activity (U/g fresh weight/min). The unit (U) for the PPO activity was defined as a change of 0.001 in absorbance at the conditions of the assay.

Total phenolic content : Total phenolic content was determined according to Rocha and Morais (2001). One banana slice per replicate was crushed and homogenized with $25 \mathrm{ml}$ water. The mixture was centrifuged (Sorvall RC-5C, Du Pont Company, Sorval Instruments, Wilmington, DE, USA) at $5010 \mathrm{rpm}$ and $4{ }^{\circ} \mathrm{C}$ for $15 \mathrm{~min}$. One $\mathrm{ml}$ of the centrifugate was allowed to react with $5 \mathrm{ml}$ Folin-Ciocalteu (FC) solution ( $1 \mathrm{ml} \mathrm{FC}$ reagent plus $9 \mathrm{ml}$ of deionized water) before adding $4 \mathrm{ml}$ of $7.5 \%(\mathrm{w} / \mathrm{v}) \mathrm{Na}_{2} \mathrm{CO}_{3}$ carbonate solution. After an hour at $30^{\circ} \mathrm{C}$ and $1 \mathrm{~h}$ at $0{ }^{\circ} \mathrm{C}$, the absorbance of the solution was measured at $760 \mathrm{~nm}$ by using the Shimadzu spectrophotometer. Dopamine was used as standard with concentrations ranging from 5 to $50 \mathrm{mg} / \mathrm{l}$ and results were expressed as mg dopamine per $100 \mathrm{~g}$ banana dry weight.

Microbiology : For the microbiological analysis, banana slices ( $10 \mathrm{~g}$ ) were removed aseptically from each package and were transferred into a sterile plastic package to which $90 \mathrm{ml}$ Ringer's sterile solution was added. The sample and the ringer solution were blended for $60 \mathrm{~s}$ by using a stomacher (400 Circulator (Seward, Thetford, Norfolk, UK).

The Portuguese standard methods, EN ISO 4833. 2003; NP 3788. 1990; NP 3277-1. 1987 were followed for counting total aerobic plate count (TPC), total coliform count and yeast and moulds count, respectively.

\section{Statistical analysis}

The SPSS 11.5 for Windows (Chicago, Illinois, USA) was used for the analysis of data. Statistical significance was assessed by oneway analysis of variance. The overall least significance difference (LSD; $p=0.05$ ) was calculated and used to detect significant differences among storage times. Relationships among measurement variables were studied by using the correlation factor $(R)$.

\section{Results and discussion}

\section{Colour and firmness}

Evaluation of colour revealed that the highest rate of browning occurred in the control after the second day of storage, as indicated by the lowest $L^{*}$ and $C$ values (Tables 1 and 2, respectively). In fact, $C$ parameter indicates the degree of saturation of colour and it is proportional to the strength of colour; López-Nicolás, Pérez-López, Carbonell-Barrachina, and García-Carmona (2007) observed a decrease in $C$ as reflex of enzymatic browning onset in banana juice. On the second day of storage, treated samples did not significantly differ from each other in terms of $L^{*}$ values (Table 1 ), while dip treatment presented the lowest $C$ value (Table 2). After 5 days of storage, dip + CA presented the highest $L^{*}$ value and the lowest changes in $L^{*}$ and $C$ values, revealing a lower browning incidence.

Dip and dip + CA had a similar effect on preventing firmness loss in banana slices during the first 2 days of storage (Table 3 ). After 5 days of storage, dip + CA treatment and control showed the lowest and highest rates of firmness loss, respectively.

\section{Water loss}

Water loss or transpiration is another factor that affects the quality of fresh-cut produce. The loss of firmness is usually associated to water loss, which is responsible by decreased turgor and crispness of fresh-cut fruits due to the absence of cuticle and exposure of internal tissues (Beaulieu \& Gorny, 2002). In fact, the control presented the highest loss of firmness and weight loss, and dip + CA treatment presented the lowest loss of firmness and

Table 1

$\mathrm{L}^{*}$ values of minimally processed banana during 5 days of storage at $5{ }^{\circ} \mathrm{C}$

\begin{tabular}{llll}
\hline Treatment & \multicolumn{2}{l}{$L^{*}$ value } & \\
\cline { 2 - 4 } & Day 0 & Day 2 & Day 5 \\
\hline Control & $79.4 \pm 1.4 \mathrm{a}$ & $63.7 \pm 6.0 \mathrm{~b}$ & $59.9 \pm 5.2 \mathrm{c}$ \\
Dip & $79.2 \pm 1.7 \mathrm{a}$ & $71.4 \pm 4.0 \mathrm{a}$ & $68.5 \pm 4.0 \mathrm{~b}$ \\
Dip + CA & $79.1 \pm 2.1 \mathrm{a}$ & $72.2 \pm 3.9 \mathrm{a}$ & $72.1 \pm 4.0 \mathrm{a}$ \\
Dip + Carrageenan + CA & $79.0 \pm 1.3 \mathrm{a}$ & $70.9 \pm 4.8 \mathrm{a}$ & $66.9 \pm 5.4 \mathrm{~b}$
\end{tabular}

Dip contains $1 \%$ calcium chloride, $0.75 \%$ cysteine and $0.75 \%$ ascorbic acid. Controlled atmosphere (CA): $3 \% \mathrm{O}_{2}$ and $10 \% \mathrm{CO}_{2}$. Different letters in the same column means significantly different $(p<0.05)$

Table 2

Chroma values of minimally processed banana during 5 days of storage at $5{ }^{\circ} \mathrm{C}$

\begin{tabular}{llll}
\hline Treatment & \multicolumn{3}{l}{ Chroma } \\
\cline { 2 - 4 } & Day 0 & Day 2 & Day 5 \\
\hline Control & $39.1 \pm 2.1 \mathrm{a}$ & $33.0 \pm 2.4 \mathrm{c}$ & $31.6 \pm 2.6 \mathrm{c}$ \\
Dip & $40.0 \pm 1.6 \mathrm{a}$ & $36.7 \pm 2.0 \mathrm{~b}$ & $34.0 \pm 2.3 \mathrm{~b}$ \\
Dip + CA & $40.0 \pm 1.3 \mathrm{a}$ & $38.9 \pm 2.9 \mathrm{a}$ & $36.8 \pm 2.7 \mathrm{a}$ \\
Dip + Carrageenan + CA & $39.4 \pm 1.4 \mathrm{a}$ & $37.8 \pm 2.1 \mathrm{a}$ & $34.6 \pm 2.9 \mathrm{~b}$ \\
\hline
\end{tabular}

Dip contains $1 \%$ calcium chloride, $0.75 \%$ cysteine and $0.75 \%$ ascorbic acid. Controlled atmosphere (CA): $3 \% \mathrm{O}_{2}$ and $10 \% \mathrm{CO}_{2}$. Different letters in the same column means significantly different $(p<0.05)$. 
Table 3

Firmness of fresh-cut banana after 5 days of storage at $5{ }^{\circ} \mathrm{C}$

\begin{tabular}{llll}
\hline Treatment & \multicolumn{3}{l}{ Firmness, N } \\
\cline { 2 - 4 } & Day 0 & Day 2 & Day 5 \\
\hline Control & $1.33 \pm 0.12 \mathrm{~b}$ & $0.93 \pm 0.06 \mathrm{~b}$ & $0.64 \pm 0.05 \mathrm{c}$ \\
Dip & $1.35 \pm 0.13 \mathrm{a}$ & $1.11 \pm 0.06 \mathrm{a}$ & $0.90 \pm 0.08 \mathrm{~b}$ \\
Dip + CA & $1.34 \pm 0.13 \mathrm{a}$ & $1.12 \pm 0.09 \mathrm{a}$ & $0.96 \pm 0.09 \mathrm{a}$ \\
Dip + Carrageenan + CA & $1.34 \pm 0.15 \mathrm{~b}$ & $0.96 \pm 0.08 \mathrm{~b}$ & $0.78 \pm 0.07 \mathrm{~b}$
\end{tabular}

Dip contains $1 \%$ calcium chloride, $0.75 \%$ cysteine and $0.75 \%$ ascorbic acid. Controlled atmosphere (CA): $3 \% \mathrm{O}_{2}$ and $10 \% \mathrm{CO}_{2}$. Different letters in the same column means significantly different $(p<0.05)$.

weight loss (Tables 3 and 4). Dip + CA showed the lowest weight loss $(0.57 \%)$, followed by dip + carrageenan + CA. In fact, when banana slices are immerged in a hypertonic sucrose solution of $1.17 \mathrm{M}$, the weight loss increases for about the double, from $4.5 \%$ to $9.7 \%$, while the firmnes loss increases about 13 times, from $1.3 \%$ to $16.9 \%$. This reveals banana tissue failure is due to rupture of the primary cell wall, and, therefore, turgor strongly affects tensile strength (Toivonen \& Brummell, 2008).

Highest weight loss was observed in control samples throughout storage. Nevertheless, it was lower than $4 \%$. According to Kays (1991), water loss of more than 4-6\% (of the total fresh weight) results in visible wilting or wrinkling of the surface of most commodities.

Relative humidity (RH) plays an important role in transpiration. According to Mir and Beaudry (2004), plant tissues tend to lose moisture when $\mathrm{RH}$ is below 99-99.5\%. The refrigerator used in the research was at around 55\% RH and this could be the reason of high weight loss of the control and dip. Furthermore, the efficacy of edible coating against water loss was shown by dip + carrageenan + CA treated samples presenting lower weight loss than control and dip treated ones. This is in agreement to Wong et al. (1994) who reported that apple slices coated with carbohydrate/lipid bilayer film presented reduced water loss between 12 and 14 times when compared to the water loss suffered by uncoated apple slices in similar storage conditions. According to Kader and Watkins (2000), modified atmosphere (MA) not only helps in retarding browning but also helps in the maintenance of high relative humidity and, therefore, reduction of water loss and, consequently, weight loss.

\section{$\mathrm{pH}$, titratable acidity and total soluble sugars}

Reduced respiration rate may be reflected in lower changes in $\mathrm{pH}$, titratable acidity (TA) and total soluble sugars (TSS) (Beaulieu \& Gorny, 2002; Kittur, Saroja, Habibunnisa, \& Tharanathan, 2001; Olivas \& Barbosa-Cánovas, 2005).

Tables 5 and 6 show the effect of chemical dip and/or coating and/or CA on $\mathrm{pH}$ and TA, respectively. Results revealed that $\mathrm{pH}$ increased as titratable acidity decreased along storage time. This was

Table 4

Weight loss of minimally processed banana during 5 days of storage at $5{ }^{\circ} \mathrm{C}$

\begin{tabular}{llll}
\hline Treatment & \multicolumn{3}{l}{ Weight loss, \% } \\
\cline { 2 - 4 } & Day 0 & Day 2 & Day 5 \\
\hline Control & 0 & $3.25 \pm 0.26 \mathrm{a}$ & $3.00 \pm 0.41 \mathrm{a}$ \\
Dip & 0 & $1.90 \pm 0.28 \mathrm{~b}$ & $2.13 \pm 0.14 \mathrm{~b}$ \\
Dip + CA & 0 & $0.00 \pm 0.00 \mathrm{~d}^{*}$ & $0.57 \pm 0.15 \mathrm{~d}$ \\
Dip + Carrageenan + CA & 0 & $1.38 \pm 0.06 \mathrm{c}$ & $1.27 \pm 0.43 \mathrm{c}$
\end{tabular}

Negative values were obtained in the three replicates. Dip contains $1 \%$ calcium chloride, $0.75 \%$ cysteine and $0.75 \%$ ascorbic acid. Controlled atmosphere (CA): $3 \% \mathrm{O}_{2}$ and $10 \% \mathrm{CO}_{2}$. Different letters in the same column means significantly different $(p<0.05)$.
Table 5

$\mathrm{pH}$ of minimally processed banana during 5 days of storage at $5{ }^{\circ} \mathrm{C}$

\begin{tabular}{llll}
\hline Treatment & $\mathrm{pH}$ & \\
\cline { 2 - 4 } & Day 0 & Day 2 & Day 5 \\
\hline Control & $4.71 \pm 0.02 \mathrm{a}$ & $4.88 \pm 0.03 \mathrm{a}$ & $5.03 \pm 0.03 \mathrm{a}$ \\
Dip & $4.69 \pm 0.03 \mathrm{a}$ & $4.84 \pm 0.04 \mathrm{a}$ & $5.02 \pm 0.04 \mathrm{a}$ \\
Dip + CA & $4.71 \pm 0.03 \mathrm{a}$ & $4.83 \pm 0.02 \mathrm{a}$ & $4.94 \pm 0.02 \mathrm{~b}$ \\
Dip + Carrageenan + CA & $4.71 \pm 0.02 \mathrm{a}$ & $4.85 \pm 0.02 \mathrm{a}$ & $4.97 \pm 0.02 \mathrm{~b}$
\end{tabular}

Dip contains $1 \%$ calcium chloride, $0.75 \%$ cysteine and $0.75 \%$ ascorbic acid. Controlled atmosphere $(\mathrm{CA}): 3 \% \mathrm{O}_{2}$ and $10 \% \mathrm{CO}_{2}$. Different letters in the same column means significantly different $(p<0.05)$.

expected because organic acids, malic acid and citric acid, which are the prevalent organic acids in banana (Wiley, 1994), were used as substrates for the enzymatic reactions of respiration.

During the first 2 days of storage, no significant difference was observed between samples. The untreated (control) banana slices presented the highest increase in $\mathrm{pH}(\sim 7 \%)$ and decrease in $\mathrm{TA}$ $(\sim 10 \%)$ at end of storage, while dip + carrageenan + CA and dip + CA showed the lowest increase in $\mathrm{pH}(\sim 5 \%)$ and decrease in TA (5-8\%).

Slowing down the respiration rate by means of chemical treatment, coating and controlling the atmosphere composition could explain the delay in the use of organic acids in the enzymatic reactions of respiration. Although no significant difference was found in the $\mathrm{pH}$ of control and dip after 5 days of storage, a significantly higher TA was found in dip treated samples than in control.

There was no direct relationship between $\mathrm{pH}$ and titratable acidity due to variation of buffer capacity of the organic acids present in the sample (Iowa State University Extension, 2007) although in general, higher acid levels in fruit are often associated with lower $\mathrm{pH}$ values and vice versa.

TSS of the control showed a significantly higher value during storage, while dip + CA showed the lowest increase in TSS along storage time. By day 2, dip + CA showed the significantly lowest value of TSS (Table 7).

The fact that the dip + CA presented the lowest TSS and relatively low $\mathrm{pH}$ at the end of storage could suggest the efficacy of

Table 6

Titratable acidity of fresh-cut banana during 5 days of storage at $5{ }^{\circ} \mathrm{C}$

\begin{tabular}{llll}
\hline Treatment & \multicolumn{4}{l}{ Titratable acidity (mg malic acid/100 g FW) } \\
\cline { 2 - 4 } & Day 0 & Day 2 & Day 5 \\
\hline Control & $661 \pm 4 \mathrm{a}$ & $630 \pm 19 \mathrm{a}$ & $595 \pm 13 \mathrm{~b}$ \\
Dip & $660 \pm 3 \mathrm{a}$ & $634 \pm 19 \mathrm{a}$ & $619 \pm 14 \mathrm{a}$ \\
Dip + CA & $660 \pm 4 \mathrm{a}$ & $649 \pm 19 \mathrm{a}$ & $627 \pm 5 \mathrm{a}$ \\
Dip + Carrageenan + CA & $661 \pm 2 \mathrm{a}$ & $636 \pm 22 \mathrm{a}$ & $610 \pm 9 \mathrm{ab}$ \\
\hline
\end{tabular}

Dip contains $1 \%$ calcium chloride, $0.75 \%$ cysteine and $0.75 \%$ ascorbic acid. Controlled atmosphere (CA): $3 \% \mathrm{O}_{2}$ and $10 \% \mathrm{CO}_{2}$. Different letters in the same column means significantly different $(p<0.05)$.

Table 7

Total soluble sugars (dry weight basis) of minimally processed banana during 5 days of storage at $5{ }^{\circ} \mathrm{C}$

\begin{tabular}{llll}
\hline Treatment & \multicolumn{4}{l}{ Total soluble sugars $(\mathrm{g}$ glucose/100 g DW) } \\
\cline { 2 - 4 } & Day 0 & Day 2 & Day 5 \\
\hline Control & $14.7 \pm 0.1 \mathrm{a}$ & $23.1 \pm 0.8 \mathrm{a}$ & $27.1 \pm 0.7 \mathrm{a}$ \\
Dip & $14.6 \pm 0.1 \mathrm{a}$ & $17.6 \pm 0.7 \mathrm{c}$ & $27.2 \pm 0.2 \mathrm{a}$ \\
Dip + CA & $14.7 \pm 0.1 \mathrm{a}$ & $15.6 \pm 0.3 \mathrm{~d}$ & $21.6 \pm 0.5 \mathrm{c}$ \\
Dip + Carrageenan + CA & $14.8 \pm 0.1 \mathrm{a}$ & $19.3 \pm 0.4 \mathrm{~b}$ & $25.6 \pm 0.7 \mathrm{~b}$ \\
\hline
\end{tabular}

Dip contains $1 \%$ calcium chloride, $0.75 \%$ cysteine and $0.75 \%$ ascorbic acid. Controlled atmosphere (CA): $3 \% \mathrm{O}_{2}$ and $10 \% \mathrm{CO}_{2}$. Different letters in the same column means significantly different $(p<0.05)$. 
CA formulation $\left(3 \% \mathrm{O}_{2}\right.$ and $\left.10 \% \mathrm{CO}_{2}\right)$ in suppressing the respiration rate of minimally processed banana, and the ripening process.

Matsuura, Cardoso, and Ribeiro (2002) characterized the banana hybrids of Pacovan cultivar. The fruit pulp showed values from 4.3 to 4.5 for $\mathrm{pH}, 0.53-0.64 \mathrm{~g}$ malic acid $/ 100 \mathrm{~g}$ for titratable acidity, $15.0-24.3 \mathrm{~g}$ glucose/100 $\mathrm{g}$ for total sugars and $22.2-27.4 \%$ for total soluble solids. In the present study, the banana $\mathrm{pH}$ was around 4.7, TA around $0.66 \mathrm{mg}$ malic acid/100 $\mathrm{g}$ and TSS around $4 \mathrm{~g}$ glucose/ $100 \mathrm{~g}$. Only the latter was highly different and inferior to values found by Matsuura et al. (2002).

\section{Polyphenol oxidase activity and total phenolic content}

Oxidation of phenolic substrates by polyphenol oxidase (PPO) is believed to be a major cause of browning of many fruits and vegetables, including banana (Nguyen, Ketsa, \& van Doorn, 2003). According to Pilar-Cano, Ancos, Lobo, and Santos (1997), the degree of browning in banana can be correlated with PPO activity and free phenolic substrates. The PPO activity and total phenolic content was, therefore, investigated to look for correlation with the browning of minimally processed banana.

Tables 8 and 9 show the PPO activity and the total phenolic content, respectively, of MP banana during storage. Dip + CA resulted in the lowest PPO activity among all treatments during all storage. Furthermore, the high PPO activity of the control on day 5 associated with the low level of total phenolic may be due to the unprotected state of the sample towards enzymatic reactions.

For dip and dip + carrageenan + CA, moderate to high negative correlations were found between the colour parameters, $L^{*}$ and $C$, and PPO activity (Table 10a). Rocha and Morais (2001) found $L^{*}$ values of Jonagored apple cubes during storage at $4{ }^{\circ} \mathrm{C}$ to be moderately correlated to PPO activity, while Lee et al. (2003) reported that peach cultivars having higher PPO activity showed a higher rate of browning and vice versa.

The control showed a large decrease in total phenolic (62\%) after 2 days of storage, while dip + CA produced the lowest decrease $(\sim 2 \%)$. Control presented the lowest total phenolic content during storage. Furthermore, high positive correlations were found between total phenolic and C for all treatments (Table 10b). Amiot,

Table 8

PPO activity of minimally processed banana during 5 days of storage at $5{ }^{\circ} \mathrm{C}$

\begin{tabular}{llll}
\hline Treatment & \multicolumn{3}{l}{ PPO activity $(\mathrm{U} / \mathrm{g}$ FW/min) } \\
\cline { 2 - 4 } & Day 0 & Day 2 & Day 5 \\
\hline Control & $20600 \pm 918 \mathrm{a}$ & $19800 \pm 1630 \mathrm{ab}$ & $39100 \pm 1580 \mathrm{a}$ \\
Dip & $19800 \pm 656 \mathrm{a}$ & $22800 \pm 1510 \mathrm{a}$ & $25700 \pm 1480 \mathrm{~b}$ \\
Dip + CA & $19900 \pm 362 \mathrm{a}$ & $18400 \pm 1680 \mathrm{~b}$ & $19400 \pm 1650 \mathrm{c}$ \\
Dip + Carrageenan + CA & $20200 \pm 605 \mathrm{a}$ & $22400 \pm 1450 \mathrm{a}$ & $28800 \pm 2140 \mathrm{~b}$ \\
\hline
\end{tabular}

Dip contains $1 \%$ calcium chloride, $0.75 \%$ cysteine and $0.75 \%$ ascorbic acid. Controlled atmosphere (CA): $3 \% \mathrm{O}_{2}$ and $10 \% \mathrm{CO}_{2}$. Different letters in the same column means significantly different $(p<0.05)$.

\section{Table 9}

Phenolic content of minimally banana during 5 days of storage at $5{ }^{\circ} \mathrm{C}$

\begin{tabular}{llll}
\hline Treatment & \multicolumn{4}{l}{ Total phenolic content (mg dopamine/100 g DW) } \\
\cline { 2 - 4 } & Day 0 & Day 2 & Day 5 \\
\hline Control & $58.2 \pm 0.5 \mathrm{a}$ & $22.1 \pm 0.3 \mathrm{~d}$ & $27.5 \pm 1.6 \mathrm{c}$ \\
Dip & $58.8 \pm 0.3 \mathrm{a}$ & $54.9 \pm 1.1 \mathrm{~b}$ & $39.4 \pm 1.1 \mathrm{~b}$ \\
Dip + CA & $58.5 \pm 0.5 \mathrm{a}$ & $57.7 \pm 0.8 \mathrm{a}$ & $42.1 \pm 1.4 \mathrm{a}$ \\
Dip + Carrageenan + CA & $58.3 \pm 0.7 \mathrm{a}$ & $50.7 \pm 0.5 \mathrm{c}$ & $39.1 \pm 1.6 \mathrm{~b}$ \\
\hline
\end{tabular}

Dip contains $1 \%$ calcium chloride, $0.75 \%$ cysteine and $0.75 \%$ ascorbic acid. Controlled atmosphere (CA): $3 \% \mathrm{O}_{2}$ and $10 \% \mathrm{CO}_{2}$. Different letters in the same column means significantly different $(p<0.05)$.
Table 10a

Correlation coefficient $\left(R^{2}\right)$ between PPO activity and other browning parameters of minimally processed banana stored at $5{ }^{\circ} \mathrm{C}$

\begin{tabular}{lllll}
\hline Quality parameter & Control & Dip & Dip + CA & Dip + Carrageenan + CA \\
\hline Colour & & & & \\
$L^{*}$ value & 0.384 & 0.942 & 0.020 & 0.792 \\
$C$ value & 0.384 & $0.998^{*}$ & 0.285 & 0.990 \\
Total phenolics & 0.116 & 0.877 & 0.567 & 0.974 \\
\hline
\end{tabular}

* Correlation is significant at the 0.05 level.

\section{Table 10b}

Correlation coefficient $\left(R^{2}\right)$ between total phenolics and colour parameters of minimally processed banana stored at $5{ }^{\circ} \mathrm{C}$

\begin{tabular}{lllll}
\hline Quality parameter & Control & Dip & Dip + CA & Dip + Carrageenan + CA \\
\hline Colour & & & & \\
L $^{*}$ value & 0.901 & 0.681 & 0.296 & 0.904 \\
C value & 0.901 & 0.850 & 0.920 & $0.996^{*}$ \\
\hline
\end{tabular}

Correlation is significant at the 0.05 level.

Fleuriet, Cheynier, and Nicolas (1997) found that $L^{*}$ was closely related to the amount of phenols degraded.

The decrease of total phenolic concentration and the increase of PPO activity during cold storage of whole banana were correlated with the development of chilling injury $(\mathrm{CI})$ and with the temperature of storage (Nguyen et al., 2003). CI injury with induced browning was causally related to the production of complex polyphenol compounds, which production was catalyzed by PPO.

\section{Microbiology}

Microbial safety is one of the most important factor to be considered for the preservation of minimally processed foods (Wiley, 1994). Banana, having a high content of water, starch and other vitamins, is an excellent source of nutrients for microorganism growth.

Total aerobic plate count (TPC) showed that, on day 0 , the total number of aerobic mesophilic microorganisms contained in all banana samples were below the detection limit, $10 \mathrm{CFU} / \mathrm{g}$ (Table 11a). However, on day 2 there was a significantly higher number of counts in the untreated sample (control) compared to other treatments. On day 5, control presented the highest microbial count, while all other treatments presented a lower count of $<30 \times 10$ $\mathrm{CFU} / \mathrm{g}$.

The same trend was also observed for total coliform and yeasts and moulds (Tables 11b and 11c). In both analyses, control gave the highest counts after 5 days of storage. On the 2 nd day of storage, a very low count was detected in all treated samples. All treated samples presented identical counting of yeast and moulds after 5 days of storage.

Table 11a

Total aerobic plate count of microorganisms of minimally processed banana during 5 days of storage at $5{ }^{\circ} \mathrm{C}$

\begin{tabular}{llll}
\hline Treatment & \multicolumn{3}{l}{ Total plate count, CFU/g } \\
\cline { 2 - 4 } & Day 0 & Day 2 & Day 5 \\
\hline Control & $<1.0 \times 10 \mathrm{a}$ & $4.2 \times 10^{2} \mathrm{a}$ & $1.6 \times 10^{4} \mathrm{a}$ \\
Dip & $<1.0 \times 10 \mathrm{a}$ & $<30 \times 10 \mathrm{~b}$ & $<30 \times 10 \mathrm{~b}$ \\
Dip + CA & $<1.0 \times 10 \mathrm{a}$ & $<30 \times 10 \mathrm{~b}$ & $<30 \times 10 \mathrm{~b}$ \\
Dip + Carrageenan + CA & $<1.0 \times 10 \mathrm{a}$ & $<30 \times 10 \mathrm{~b}$ & $<30 \times 10 \mathrm{~b}$ \\
\hline
\end{tabular}

Dip contains $1 \%$ calcium chloride, $0.75 \%$ cysteine and $0.75 \%$ ascorbic acid. Controlled atmosphere (CA): $3 \% \mathrm{O}_{2}$ and $10 \% \mathrm{CO}_{2}$. Different letters in the same column means significantly different $(p<0.05)$ 
Table 11b

Total coliform count of minimally processed banana during 5 days of storage at $5{ }^{\circ} \mathrm{C}$

\begin{tabular}{llll}
\hline Treatment & \multicolumn{4}{l}{ Total coliform, CFU/g } \\
\cline { 2 - 4 } & Day 0 & Day 2 & Day 5 \\
\hline Control & $<1.0 \times 10 \mathrm{a}$ & $<15 \times 10 \mathrm{a}$ & $1.6 \times 10^{3} \mathrm{a}$ \\
Dip & $<1.0 \times 10 \mathrm{a}$ & $<15 \times 10 \mathrm{a}$ & $2.1 \times 10^{2} \mathrm{~b}$ \\
Dip + CA & $<1.0 \times 10 \mathrm{a}$ & $<15 \times 10 \mathrm{a}$ & $<15 \times 10 \mathrm{c}$ \\
Dip + Carrageenan + CA & $<1.0 \times 10 \mathrm{a}$ & $<15 \times 10 \mathrm{a}$ & $<15 \times 10 \mathrm{c}$
\end{tabular}

Dip contains $1 \%$ calcium chloride, $0.75 \%$ cysteine and $0.75 \%$ ascorbic acid. Controlle atmosphere (CA): $3 \% \mathrm{O}_{2}$ and $10 \% \mathrm{CO}_{2}$. Different letters in the same column means significantly different $(p<0.05)$.

Table 11c

Yeasts and moulds count of minimally processed banana during 5 days of storage at $5{ }^{\circ} \mathrm{C}$

\begin{tabular}{llll}
\hline Treatment & \multicolumn{3}{l}{ Yeasts and moulds, CFU/g } \\
\cline { 2 - 4 } & Day 0 & Day 2 & Day 5 \\
\hline Control & $<1.0 \times 10 \mathrm{a}$ & $<15 \times 10 \mathrm{a}$ & $5.1 \times 10^{3} \mathrm{a}$ \\
Dip & $<1.0 \times 10 \mathrm{a}$ & $<15 \times 10 \mathrm{a}$ & $<15 \times 10 \mathrm{~b}$ \\
Dip + CA & $<1.0 \times 10 \mathrm{a}$ & $<15 \times 10 \mathrm{a}$ & $<15 \times 10 \mathrm{~b}$ \\
Dip + Carrageenan + CA & $<1.0 \times 10 \mathrm{a}$ & $<15 \times 10 \mathrm{a}$ & $<15 \times 10 \mathrm{~b}$
\end{tabular}

Dip contains $1 \%$ calcium chloride, $0.75 \%$ cysteine and $0.75 \%$ ascorbic acid. Controlled atmosphere (CA): $3 \% \mathrm{O}_{2}$ and $10 \% \mathrm{CO}_{2}$. Different letters in the same column means significantly different $(p<0.05)$.

The counts observed for the control on day 5 showed that it was a better medium for microbial growth than treated samples. Its sugar content (Table $7 \mathrm{~b}$ ) and $\mathrm{pH}$ value (Table 5) were propitious for either yeasts or moulds proliferation. However, TPC and yeasts and moulds counts during the storage are still well below the critical limits: Jacxsens, Devlieghere, and Debereve (2002) reported that the critical limits for TPC and yeasts and moulds for vegetables are $10^{8} \mathrm{CFU} / \mathrm{g}$ and $10^{5} \mathrm{CFU} / \mathrm{g}$, respectively.

Chemically dipped bananas, on the other hand, presented an even lower increase in microbial load. This can be explained by the relative high acidity of the dip. The natural $\mathrm{pH}$ of the dip was 2.60 , and, at this $\mathrm{pH}$, no to few number of microorganisms was found to grow until day 2. According to Wiley (1994), organic acids like ascorbic acid (one of the components of the chemical dip) may also possess bactericidal properties. The antimicrobial action of organic acids is due to $\mathrm{pH}$ reduction in the environment, disruption of membrane transport and/or permeability, anion accumulation, or a reduction in internal cellular $\mathrm{pH}$ by the dissociation of hydrogen ions from the acid.

As shown in Table $11 \mathrm{~b}$, reducing the respiration rate by controlled atmosphere may not only retard ethylene production but also microbial load. Among the gases involved in $\mathrm{CA}$, only $\mathrm{CO}_{2}$ has a direct antimicrobial effect that results in an increased lag phase and generation time during the logarithmic phase of growth of the organisms involved (Phillips, 1996), with inhibition being dependent on gas concentration and temperature. According to Parry (1993), nitrogen in modified atmosphere packaging helps in three ways: (1) displacement of $\mathrm{O}_{2}$ to delay oxidation, (2) retardation of the growth of aerobic spoilage organism and (3) action as a filler to maintain package conformity. The film, used to create MA, could have also helped to alter growth rate of spoilage and pathogenic microorganism. Olivas and Barbosa-Cánovas (2005) defend that MA created by coating may change the growth rate of spoilage and pathogenic bacteria: MA may inhibit the growth of organisms usually responsible for spoilage, while encouraging the growth of pathogens. In the present study, dip + CA and dip + carrageenan + CA treatments, compared to the control, exhibited low microbial growth rates after 5 days of storage.

\section{Conclusion}

Chemical dip combined with controlled atmospheres presented the lowest rate of browning and firmness in banana slices after 5 days of storage at $5{ }^{\circ} \mathrm{C}$. The fact that the dip + CA presented the lowest TSS and relatively low $\mathrm{pH}$ at the end of storage could suggest efficacy in suppressing the respiration rate of minimally processed banana. Chemical dip, coating and controlled atmosphere might have altered the growth rate of spoilage and pathogenic microorganisms.

This study showed that dipping into chemical solution $(0.5 \%$ ascorbic acid, $2 \%$ calcium chloride and $0.75 \%$ cysteine) combined with carrageenan coating plus storage under controlled atmosphere $\left(3 \% \mathrm{O}_{2}\right.$ and $\left.10 \% \mathrm{CO}_{2}\right)$ could be a good method to preserve fresh-cut bananas for 5 days at $5{ }^{\circ} \mathrm{C}$. However, dipping associated to $\mathrm{CA}$ revealed itself an even better alternative.

\section{Acknowledgements}

The authors acknowledge financial support from project SEFOTECH.NUT (Erasmus Mundus programme 28027-IC-6-2001-BEERASMUS-EPS-1). The authors thank CPKelco for offering the carrageenan.

\section{References}

Abe, K., \& Watada, A. E. (1991). Ethylene absorbent to maintain quality of lightly processed fruits and vegetables. Journal of Food Science, 56, 1589-1592.

Aguayo, E., Escalona, V. H., \& Artés, F. (2008). Effect of hot water treatment and various calcium salts on quality of fresh-cut Amarilló melon. Postharvest Biology and Technology, 47, 397-406.

Amiot, J. M., Fleuriet, A., Cheynier, V., \& Nicolas, J. (1997). Phenolic compounds and oxidative mechanisms in fruit and vegetables. In F. A. Tomas-Barberán \& R. J. Robins (Eds.), Phytochemical Society of Europe (pp. 51-85). Oxford: Clarendon Press.

Baldwin, E. A., Nisperos, M. O., Chen, X., \& Hagenmaier, R. D. (1996). Improving storage life of cut apple and potato with edible coating. Postharvest Biology and Technology, 9, 151-163.

Baldwin, E. A., Nisperos-Carriedo, M. O., \& Baker, R. A. (1995). Use of edible coatings to preserve quality of lightly (and slightly) processed products. Critical Reviews in Food Science and Nutrition, 35, 509-524

Beaulieu, J.C., Gorny, J.R. (2002). Fresh-cut Fruits. <http://www.ba.ars.usda.gov/ hb66/146freshcutfruits.pdf> (accessed 1.12.2007).

Brecht, J. K. (1999). Postharvest quality and safety in fresh-cut vegetables and fruits. Cooperative Regional Research Project S-294.

Chervin, C., \& Boisseau, P. P. (1994). Quality maintenance of ready-to-eat shredded carrots by gamma irradiation. Journal of Food Science, 59, 359-361.

Commission Internationale de L'Eclairage (CIE) (1978). Recommendations on uniform color spaces - color-difference equations, psychometric color terms. CIE, Paris. Publ. 15, Suppl. 2.

Debeaufort, F., Quezada-Gallo, J. A., \& Voilley, A. (1998). Edible films and coatings: Tomorroẃs packaging: A review. Critical Reviews in Food Science, 38, 299-313.

Gorris, L. G. M., \& Tauscher, B. (1999). Quality and safety aspects of novel minimal processing technologies. In F. A. R. Oliveira \& J. C. Oliveira (Eds.), Processing foods. Quality optimization and process assessment (pp. 325-339). New York: CRC Press.

Guilbert, G., \& Biquet, B. (1996). Edible Films and Coatings. In G. Bureau \& J. L Multon (Eds.). Food Packaging Technology (Vol. 1, pp. 315-353). New York: VCH Publishers Inc.

Hong, J. H., \& Gross, K. C. (1998). Surface sterilization of whole tomato fruit with sodium hypochlorite influences subsequent postharvest behavior of fresh-cut slices. Postharvest Biology and Technology, 13, 51-58.

Iowa State University Extension, (ISUE). 2007. Titratable Acidity. <http:// www.extension.iastate.edu/Wine/Resources/titratableacidity.htm> (accessed 20.12.2007).

ISO 4833. (2003). Microbiology of food and animal feeding stuffs-Horizontal method for the enumeration of microorganisms-colony-count technique at $30^{\circ} \mathrm{C}$. International Organisation for Standardisation. Geneva, Switzerland.

Jacxsens, L., Devlieghere, F., \& Debereve, J. (2002). Predictive modelling for packaging design: equilibrium modified atmosphere packages of fresh-cut vegetables subjected to a simulated distribution chain. International Journal of Food Microbiology, 73, 331-341.

Kader, A. (2005). Banana: Recommendations for Maintaining Postharvest Quality. <http://rics.ucdavis.edu/postharvest2/Produce/ProduceFacts/Fruit/banana.shtml> (accessed 13.5.2007)

Kader, A. A., \& Watkins, C. B. (2000). Modified Atmosphere Packaging - Toward 2000 and Beyond. HortTechnology, 10, 483-486. 
Kays, S. J. (1991). Postharvest physiology of perishable plant products. New York: Van Nostrand Reinhold.

Kittur, F. S., Saroja, N., Habibunnisa, \& Tharanathan, R. N. (2001). Polysaccharidebased composite formulations for shelf-life extension of fresh banana and mango. European Food Research and Technology, 213, 306-311.

Lee, J. Y., Park, H. J., Lee, C. Y., \& Choi, W. Y. (2003). Extending shelf-life of minimally processed apples with edible coatings and antibrowning agents. LebensmittelWissenschaft und-Technologie, 36, 323-329.

López-Nicolás, J. M., Pérez-López, A. J., Carbonell-Barrachina, A., \& García-Carmona, A. (2007). Kinetic study of the activation of banana juice enzymatic browning by the addition of matoxyl-B-cyclodextrin. Journal of Agriculture and Food Chemistry, 55, 9655-9662.

Madamba, L. S. P. (1993). Technical analysis I. Foods and feeds. Laguna, Philippines: Institute of Chemistry, University of the Philippines Los Banos.

Matsuura, F. C. A. U., Cardoso, R. L., \& Ribeiro, D. E. (2002). Qualidade sensorial de frutos de hybridos de bananeira cultivar Pacovan. Revista Brasileira de Fruticultura, 24, 263-266.

McHugh, T. H., \& Senesi, E. (2002). Apple wraps: A novel method to improve the quality and extend the shelf life of fresh-cut apples. Journal of Food Science, 65, 480-485.

Mir, N., \& Beaudry, R. M. (2004). Modified Atmosphere Packaging. <www.ba.ars.usda.gov/hb66/015map.pdf> (accessed 20.12.2007).

Nguyen, T. B. T., Ketsa, S., \& van Doorn, W. G. (2003). Relationship between browning and the activities of polyphenol oxidase and phenylalanine ammonia lyase in banana peel during low temperature storage. Postharvest Biology and Technology, 30, 187-193.

NP 3277-1. (1987). IPQ, Microbiologia Alimentar. Contagem de bolores e leveduras. Parte 1: Incubação a $25^{\circ} \mathrm{C}$. Lisbon.

NP 3788. (1990). IPQ Microbiologia Alimentar. Regras gerais para a contagem de bactérias coliformes a $30^{\circ} \mathrm{C}$. Lisbon.

Olivas, G. I., \& Barbosa-Cánovas, G. V. (2005). Edible coatings for fresh-cut fruits. Critical Reviews in Food Science and Nutrition, 45, 657-670.

Olivas, G. I., Rodriguez, J. J., \& Barbosa-Cánovas, G. V. (2003). Edible coatings composed of methylcellulose, stearic acid, and additives to preserve quality of pear wedges. Journal of Food Processing and Preservation, 27, 299-320.

Parry, R. T. (1993). Introduction. In R. T. Parry \& B. A. Blakistone (Eds.), Principles and applications of MAP of foods (pp. 1-18). New York: Blackie Academic and Professional.
Pavlath, A. E., Wong, D. S. W., \& Kumosinski, T. F. (1993). New coating for cut fruits and vegetables. Chemtechnology, 36-40.

Phillips, C. A. (1996). Review: modified atmosphere packaging and its effects on the microbiological quality and safety of produce. International Journal of Food Science and Technology, 3, 463-479.

Pilar-Cano, M., Ancos, B., Lobo, M. G., \& Santos, M. (1997). Improvement of frozen banana (Musa cavendishii, cv. Enana) colour by blanching: relationship between browning, phenols and polyphenol oxidase and peroxidase activities. Lebensmittel Unters Forsch A, 204, 60-65.

Purvis, A. C. (1983). Effects of film thickness and storage temperature on water loss and internal quality of seal-packaged grapefruit. Journal of American Society of Horticultural Science, 108, 562-566.

Rocha, A. M. C. N., \& Morais, A. M. M. B. (2001). Polyphenoloxidase activity and total phenolic content as related to browning of minimally processed 'Jonagored' apple. Journal of the Science of Food and Agriculture, 82, 120-126.

Rouse, A. H., \& Moore, E. L. (1972). All-purpose gel blend for preparing citrus gels Proceedings of the Florida State Horticultural Society, 79, 229-232.

Soliva-Fortuny, R. C., \& Martin-Belloso, O. (2003). New Advances in extending the shelf-life of fresh-cut fruits: A Review. Trends in Food Science and Technology, 14, 341-353.

Thommohaway, C., Uthairatanakij, A., Kanlayanarat, S., \& Jitareerat, P. (2007). Quality of fresh-cut guava (Psidium Guajava L.) as affected by chitosan treatment. Acta Horticulture, 746, 449-454.

Toivonen, P. M. A., \& Brummell, D. A. (2008). Biochemical bases of appearance and texture changes in fresh-cut fruit and vegetables. Postharvest Biology and Technology, 48, 1-14.

Vilas-Boas, E. V., \& Kader, A. A. (2006). Effect of atmospheric modification, 1-MCP and chemicals on quality of fresh-cut banana. Postharvest Biology and Technology, 39, 155-162.

Vojdani, F., \& Torres, A. (1990). Potassium sorbate permeability of methylcellulose and hydroxypropyl methylcellulose coatings: Effect of fatty acids. Journal of Food Science, 55, 841-846.

Wiley, R. C. (1994). Minimally processed refrigerated fruits and vegetables. New York. London: Chapman and Hall.

Wong, D. W. S., Tillin, S. J., Hudson, J. S., \& Pavlath, A. E. (1994). Gas exchange in cut apples with bilayer coatings. Journal of Agricultural Food Chemistry, 42, 2278-2285. 